\title{
IDENTIFICATION, SPREAD AND HARMFULNESS OF BUCKWHEAT MYCOPLASMOSIS
}

\author{
V. K. Shevchuk', O. A. Demchenko ${ }^{2,4}$, L. V. Yuzvenko, \\ V. H. Radchenko ${ }^{4}$, A. L. Boiko ${ }^{3}$ \\ ${ }^{1}$ Podillia State Agrarian and Technical University \\ 13, Shevchenka Str.; Kamianets-Podilskyi City, Khmelnytsk region, 32300, Ukraine \\ ${ }^{2}$ Danylo Zabolotny Institute of Microbiology and Virology, NAS of Ukraine, Kyiv \\ 154, Akademika Zabolotnoho Str., Kyiv City, MSP D03143, Ukraine \\ ${ }^{3}$ Taras Shevchenko National University of Kyiv \\ 60, Volodymyrska Str.; Kyiv City, 01601, Ukraine \\ ${ }^{4}$ Institute for Evolutionary Ecology of NAS of Ukraine \\ 37, Akademika Lebedieva Str.; Kyiv City, 03143, Ukraine \\ e-mail: spivak-spivak-n@ya.ru
}

Plant mycoplasmal diseases are widespread in the world. A number of Phytoplasmas are known which belong to more than 30 groups and are pathogens for diseases that affect more than 200 plant species. It had been thought for a long time that viruses cause them, although no pathogens were isolated or visualized. In 1967 Japanese scientists [1] revealed the structures morphologically similar to animal pathogens - mycoplasma - in ultrathin sections of aster plant phloem, diseased with chlorosis. Those new plant pathogens were named mycoplasma-like organisms and classified as Mollicutes, i.e. bacteria without cell wall.

In the early 90-ies, based on phylogenetic analysis of DNA sequences of those organisms it was shown that they are a great monophyletic (i.e. derived from one ancestor) group within Mollicutes class and the name "phytoplasma" was suggested for them. Other representatives of this class were Mycoplasmas, Acholeplasmas and Spiroplasmas, closest to such bacteria as Bacillus, Clostridium, Streptococcus. Current trivial name "phytoplasma" was officially adopted in 1994 at the $10^{\text {th }}$ Congress of the International Organization of Mycoplasmologists to replace the term "mycoplasma-like organisms" [2]. Today phytoplasmas are separated as "Candidates Phytoplasma" genus. Candidates category is used to refer to organisms that cannot be grown in vitro. The first 20 Candidates species were attributed to this genus on the basis that the identity of the DNA nucleotide sequence of $16 \mathrm{~S}$ rRNA gene was at least $97.5 \%[3]$.

These pathogens are well identified in transmissible and scanning electron microscopy. Thus, wheat and hops phytoplasma were examined during the study of homogenates and ultrathin sections of cells. [4]

Phytoplasma cause diseases of economically important crops, including buckwheat - valuable cereal crop. Its fruits contain $12-18 \%$ of protein, $2-4 \%$ of fat, $70-$ $85 \%$ of starch. For its nutritional value, taste and dietary properties buckwheat cereal is considered one of the most important food products used in cooking to prepare different dishes [5]. In addition, buckwheat is a rich melliferous plant.

One of the factors limiting obtaining high buckwheat yields is its affection by diseases. Buckwheat phytoplasma infestation belongs understudied diseases and was first identified by S. F. Sydorova in 1965. At that this pathogen was not visualized [6].

The objective of our research is to study the features of this disease pathogen spreading and to study its morphological characteristics.

Materials and methods. To identify buckwheat phytoplasma route survey of 
buckwheat crops and stationary experiments with buckwheat were conducted. Buckwheat mycoplasmosis harmfulness was determined by comparing the elements of morphobiometric performance of diseased and healthy plants.

To prove the pathogenicity of buckwheat phytoplasma pathogen visual diagnosis and engrafting of diseased plants upon plant indicator (rosy periwinkle Catharanthus roseus G. Don) were used. The infection was performed by cleft grafting. The observation was conducted during the month.
In order to visualize and localize the pathogen electron microscopic examination was carried out. The contrasting was performed using uranyl acetate and phosphotungstic acid (PTA).

To study mixed infection in buckwheat plants (mycoplasma, fungi, viruses, bacteria) conventional methods for pathogen detection were used [7].

So, through the analysis of diseased buckwheat plants we found and identified phytoplasma (mycoplasma), allowing further conducting targeted research and development of pathogen control measures. 